\title{
THE UNDERLYING PATHOLOGY OF AUTOIMMUNE THYROID DISEASE IS IL-22 INDEPENDENT
}

\author{
Hadi H. Hamad ${ }^{\text {a }}$, Amir H. Raziq ${ }^{\text {b }}$ \\ ${ }^{a}$ Dept. of Biology, College of Science, University of Duhok, Kurdistan Region, Iraq (hadi.hamad@uod.ac) \\ b Scientific Research Centre, College of Science, University of Duhok, Kurdistan Region, Iraq (amir.razig@uod.ac)
}

Received: Mar., 2020 / Accepted: May., 2020 / Published: Jun.,2020

https://doi.org/10.25271/sjuoz.2020.8.2.710

\begin{abstract}
:
The thyroid gland is frequently associated with autoimmune disease. It produces thyroid hormones responsible for controlling cellular metabolism. The current case control study involved ninety subjects which were assigned into two equal-numbered groups of patients and apparently healthy controls. For laboratory evaluation, five millilitres of venous blood were withdrawn from individual participants, serum were collected and stored at $-20{ }^{\circ} \mathrm{C}$ to be analysed. Immunoassay technique was used to measure the serum level of thyroid stimulating hormone (TSH), thyroxine (T4), and triiodothyronine (T3). While ELISA technique was used for measuring the serum levels of anti-thyroid peroxidase (anti-TPO) antibodies and IL-22. The results of the current study showed that, in the patient group, thirty eight $(84.44 \%)$ subjects were diagnosed with hypothyroidism, represented by thirty five female $(77.77 \%)$ and three male $(6.67 \%)$; furthermore, seven individuals $(15.56 \%)$ were grouped as hyperthyroid patients and represented by five females $(11.11 \%)$ and two males $(4.45 \%)$. The results also demonstrated that the serum TSH levels (12.04 $\pm 2.76)$ for the patients were significantly $(\mathrm{p}<0.05)$ higher than that of the control group $(1.87 \pm 0.15)$. Whereas, T3 and T4 mean serum levels \pm SE were $2.05 \mathrm{nmol} / 1 \pm 0.14 ; 100.66 \mathrm{nmol} / 1 \pm 4.76$ and $2.14 \mathrm{nmol} / 1 \pm 0.07 ; 105.37 \mathrm{nmol} / 1 \pm 2.92$ for patient and control categories, respectively. The findings of this work showed that mean serum level $(\mathrm{IU} / \mathrm{ml})$ of anti-thyroidperoxidase antibody in patient group differed significantly $(\mathrm{P}<0.05)$ in comparison to control group (represented by $259.08 \pm 59.99$ and 8.71 \pm 1.23 , respectively). No statistical difference was non-significant when comparison involved mean serum concentration levels of IL-22 for patients $(157.22 \mathrm{ng} / \mathrm{ml} \pm 24.81)$ and controls $(157.08 \mathrm{ng} / \mathrm{ml} \pm 24.80)$. In conclusion: IL-22 cannot be proposed as an essential factor participating the development and/or the progression of autoimmune thyroid disease (AITD).
\end{abstract}

KEYWORDS: Autoimmune diseases, Anti-TPO, ELISA, IL-22

\section{INTRODUCTION}

Autoimmune diseases are an exaggerated general dilemma affecting nowadays community (Przybylik-Mazurek et al., 2007). Epidemiological investigations performed over the last several years ascertained that $3-8 \%$ of population from the entire world develop autoimmune diseases (Szczeblowska et al., 2011).

The thyroid is a hormone-producing gland most likely had an autoimmune disorder than any organ (Shevach, 2009). Clinically, the most abundant manifestations of thyroid autoimmune diseases are Graves' disease and Hashimoto's thyroiditis; both conditions are accompanied by a varying degrees of lymphocytic infiltration of the thyroid tissue as well as the development of self-reactive autoantibodies against thyroid antigens such as thyroglobulin (TG), thyroid peroxidase (TPO), and thyroid stimulating hormone receptor (TSHR) (Guo et al., 2018).

Thyroid autoimmune disorders ensue as a consequence of the interactions between environmental and genetic elements and are manifested by generating an immune response against thyroid antigens which is attributed to autoreactive immune cells bypassing immunological tolerance. Both humoral immune responses and cell-mediated immunity result in tissue damage in autoimmune thyroid disorder. Due to dominance of specific immune mediators in particular setting, CD4+ cells differentiation culminates in the development of variable T cell subsets. Identification of $\mathrm{T}$ cells has revealed a mosaic pattern of cytokine secretion emphasizing that both, $\mathrm{T}$ helper 1 and $\mathrm{T}$ helper 2, activation participated in all kinds of autoimmune thyroid diseases. More recently, research denoted $\mathrm{T}$ cell subtypes involving Treg and Th17 as having profound roles in the establishment of AITD (Rydzewska et al, 2018).

The involvement of Th17 cells in the immune responses against extracellular microbes is well established beside their capability to liberate cytokines: IL-17, IL-17F, IL-21, IL-22 and IL-23 (Bossowski et al., 2013), which are described as a pro-inflammatory cytokines that contribute to the development of autoimmune disease (Peng et al., 2013).

Cytokines are involved in the pathogenesis of autoimmune phenomena. The actual initiator of the self-tolerance disturbances with the resultant outcomes culminating in the triggering of pathologic autoimmune reaction remain to be elucidated for the majority of the existing autoimmune disorders. Recently, the interleukin IL-17/IL-23 axis has been shown as the new paradigm which led significantly to reevaluate the cytokine-induced immune circumstances in the initiation, propagation, and treatment of autoimmune disorders (Moudgi and Choubey, 2011).

In this study, we aimed to determine and compare serum concentration of IL-22 in autoimmune thyroid patients versus controls healthy subjects in Duhok province.

\section{MATERIALS AND METHODS}

\subsection{Participants:}

Ninety patients and healthy control subjects (8-80 years old), 45 Patients and 45 Control; were enrolled in the present study.

\footnotetext{
* Corresponding author

This is an open access under a CC BY-NC-SA 4.0 license (https://creativecommons.org/licenses/by-nc-sa/4.0/)
} 
A questionnaire form was submitted to every participant which reported information such as sex, age, geographical location, and marital status. Candidate subjected were selected from those who had been referred to Duhok central health laboratory from November 2018 to May 2019. Preliminary investigation was performed as the candidate patients suffered clinical symptoms suggestive of malfunctioning thyroid gland. A document verifying preliminary diagnosis was submitted to each patient.

\subsection{Collection Of Blood Samples:}

Five milliliters $(\mathrm{ml})$ of venous blood were collected from each individual (patient and control), left at room temperature for 20-25 minute to clot, and then centrifuged for ten minutes at 3000 round per minute (rpm); serum was stored at $-20^{\circ} \mathrm{C}$ to be analysed. Cobas e411 instrument was used to measure the serum concentration of TSH, T4 and T3, Electrochemiluminescence (ECL) is Roche's technology for immunoassay detection. ELISA method was used for measuring the serum levels of anti-TPO antibodies and IL-22. The manufacturer's instructions were precisely implemented.

\section{STATISTICAL ANALYSIS}

Data were represented as the mean \pm standard error Comparisons between groups were conducted using the student $\mathrm{t}$ test (independent samples). $\mathrm{P}<0.05$ was considered to describe a statistically significant difference. Statistical results were obtained using SPSS (IBM Corporation, New York, NY, USA, Version 26.0)

\section{RESULTS}

The results of this work demonstrated that, in the patient group, thirty eight $(84.44 \%)$ subject were diagnosed with hypothyroidism as per their TSH serum level, represented by thirty five females $(77.77 \%)$ and three males $(6.67 \%)$; furthermore, seven individuals $(15.56 \%)$ were grouped as hyperthyroid patient and represented by five females $(11.11 \%)$ and two males $(4.45 \%)$ (Table 1$)$.

Table 1 . The frequency and gender of hyper and hypothyroid patients.

\begin{tabular}{|c|c|c|c|c|c|c|}
\hline \multirow{2}{*}{ Gender } & \multicolumn{2}{|c|}{ Hypothyroid } & \multicolumn{2}{c|}{ Hyperthyroid } & \multicolumn{2}{c|}{ Total } \\
\cline { 2 - 7 } & $\begin{array}{c}\text { Frequenc } \\
\mathrm{y}\end{array}$ & $\begin{array}{c}\text { Percentage } \\
(\%)\end{array}$ & $\begin{array}{c}\text { Frequenc } \\
\mathrm{y}\end{array}$ & $\begin{array}{c}\text { Percenta } \\
\text { ge (\%) }\end{array}$ & $\begin{array}{c}\text { Frequenc } \\
\mathrm{y}\end{array}$ & $\begin{array}{c}\text { Percentage } \\
(\%)\end{array}$ \\
\hline Male & 3 & 6.67 & 2 & 4.45 & 5 & 11.12 \\
\hline Female & 35 & 77.77 & 5 & 11.11 & 40 & 88.88 \\
\hline Total & 38 & 84.44 & 7 & 15.56 & 45 & 100.0 \\
\hline
\end{tabular}

The findings of the present study demonstrated that mean TSH serum concentration $(\mathrm{uIU} / \mathrm{ml})$ and standard error $( \pm \mathrm{SE})$ of $12.04 \pm 2.76$ for the patients which profoundly exceeded that of the controls $1.87 \pm 0.15$; and statistically significant difference $(\mathrm{P}<0.05)$ was obtained. Whereas, T3 and T4 mean serum levels $(\mathrm{nmol} / \mathrm{l}) \pm \mathrm{SE}$ were $2.05 \pm 0.14 ; 100.66 \pm 4.76$ and $2.14 \pm 0.07 ; 105.37 \pm 2.92$ for patient and control groups, respectively. The comparison of the two categories indicated no significant difference $(\mathrm{p}<0.05)$ (Table 2$)$.
Table 2: The means of TSH and thyroid hormones serum levels for patient and controls.

\begin{tabular}{|c|c|c|c|c|}
\hline Hormones & Group & Frequency & $\begin{array}{l}\text { Mean serum level } \pm \\
\text { SE }\end{array}$ & $\mathrm{p}$ value \\
\hline \multirow{2}{*}{$\begin{array}{c}\mathrm{TSH} \\
(\mathrm{uIU} / \mathrm{ml})\end{array}$} & Patient & 45 & $12.04 \pm 2.76$ & \multirow{2}{*}{$.000 *$} \\
\hline & Control & 45 & $1.87 \pm 0.15$ & \\
\hline \multirow{2}{*}{$\begin{array}{c}\mathrm{T} 3 \\
(\mathrm{nmol} / 1)\end{array}$} & Patient & 45 & $2.05 \pm 0.14$ & \multirow[b]{2}{*}{0.11} \\
\hline & Control & 45 & $2.14 \pm 0.07$ & \\
\hline \multirow{2}{*}{$\begin{array}{c}\mathrm{T} 4 \\
(\mathrm{nmol} / \mathrm{l})\end{array}$} & Patient & 45 & $100.66 \pm 4.76$ & \multirow[b]{2}{*}{0.06} \\
\hline & Control & 45 & $105.37 \pm 2.92$ & \\
\hline
\end{tabular}

*Significance at $P<0.05$

In this study, the mean serum concentration of anti-TPO antibody differed significantly $(\mathrm{P}<0.05)$ when the two candidate categories were compared (Table 3 ).

Table 3. Comparison of the mean Anti-TPO serum concentration for patients and controls.

\begin{tabular}{|c|c|c|c|c|}
\hline & Category & Frequency & $\begin{array}{c}\text { Mean Anti- } \\
\text { thyroidperoxi } \\
\text { dase serum } \\
\text { level } \pm \text { SE }\end{array}$ & p value \\
\hline \multirow{2}{*}{$\begin{array}{c}\text { Anti- } \\
\text { TPO } \\
\text { (IU/ } \\
\text { ml) }\end{array}$} & Patients & 45 & $259.08 \pm 59.99$ & \multirow{2}{*}{$.000^{*}$} \\
\cline { 2 - 4 } & Controls & 45 & $8.71 \pm 1.23$ & \\
\hline
\end{tabular}

*Significant at $P<0.05$

Furthermore, when comparison involved mean serum concentration (ng/l) levels of IL-22 of patients (157.22 \pm 24.81$)$ and controls $(157.08 \pm 24.80)$, no statistical significant difference $(\mathrm{p}<0.05)$ appeared (Table 4$)$.

Table 4. Mean serum conc. \pm SE of Interleukin-22 for both patient and control.

\begin{tabular}{|c|c|c|c|}
\hline Interleukin & $\begin{array}{c}\text { Patients (mean } \\
\text { serum conc. } \\
\mathrm{ng} / \mathrm{l} \pm \mathrm{SE})\end{array}$ & $\begin{array}{c}\text { Controls (mean } \\
\text { serum conc. } \\
\pm \mathrm{SE})\end{array}$ & $\mathrm{p}$ value \\
\hline $\begin{array}{c}\text { Interleukin-22 } \\
(\mathrm{ng} / \mathrm{l})\end{array}$ & $157.22 \pm 24.81$ & $157.08 \pm 24.80$ & 0.06 \\
\hline
\end{tabular}

\section{DISCUSSION}

The anterior pituitary hormone (thyroid stimulating hormone) is considered a fundamental biomarker for assessment of normal thyroid status and is useful in directing treatment strategies for hypothyroid and hyperthyroid subjects. The amplified response of TSH to minor alterations in thyroid hormone profiles provides a meaningful and directly estimated signal in the routine care setting. Laboratories submit reference ranges for TSH with lower and upper limits to define normal thyroid function (Razvi, et al., 2019). Thyroid dysfunction is often characterized by nonspecific symptoms, and diagnosis is ascertained by laboratory testing for T3, T4, and TSH. Nowadays systematic approach for the diagnosis and treatment of thyroid disorders focuses mainly on the measurement of $\mathrm{TSH}$, as the highly sensitive and specific indicator of systemic thyroid status, with test findings interpreted as per defined reference range (Jonklaas et al., 2014; Okosieme et al., 2016). Majority of autoimmune cases are more prevalent in females than males; conservative estimates announce that approximately $80 \%$ of autoimmune diseases victims are women (Viswanath, 2013). Hashimoto's thyroiditis generally affects women between forty-five and sixty-five years old, with a female to male ratio of 10:1. Graves' disease is ten times more frequent in females than males (Vanderpump, 2005). The above-mentioned gender differences seem to indicate the 
profound impact of sex hormones on the normal functioning of immune system, and investigations have explored this matter to demonstrate the influence on autoimmune diseases (Cutolo et al., 2006). Former studies revealed that the inactivated Barr body in women is still partially active, and up to $15 \%$ of $\mathrm{X}$ chromosome genes can thus be expressed by both chromosomes (Rubtsov et al., 2010). The genetic mutations and the skewed DNA may influence the second X-chromosome activation, a condition which has been manifested more frequently in individuals with an autoimmune disorder, compared to healthy subjects (Brown, 1999; Oliver and Silman, 2009). Not surprisingly, the findings of this work were consistent with the general consensus which stated that females are much more prone to thyroid autoimmunity than males and the most affected people are those at the adulthood age and older (Canaris et al., 2000; Hollowell et al., 2002; Gussekloo et al., 2004; Flynn et al., 2004; Leese et al., 2008)

The observations obtained in this study were in accordance with others who found 79 out of 215 patients had elevated serum thyroid stimulating hormone levels, but contradict the same research findings when consider the 136 patients out of the same total to have TSH serum level slightly above normal value(Sridevi et al., 2018). It was found that patients had significantly higher TSH concentrations compared to controls $(p<0.001)$ but no difference between the two groups when fT4 levels were considered, the later mentioned findings were in line with those of the present work.

From the population of 5.962 subjects, $24.5 \%$ showed changing TSH values $(19.0 \%$ with elevated TSH concentrations suggestive of hypothyroidism); despite with a higher percentages value of hypothyroid individuals due to the inclusion criteria (Carmona et al., 2018), the above results mimic those of the present study.

In accordance with the results of the current study, after evaluating 472 subjects attending occupational health centers in Chile, it was noted that frequency of thyroid alterations was two times greater in women than men (Fardella et al., 2001).

The presence of a high anti-TPO Abs is a distinctive feature of autoimmune thyroid disorders, especially Hashimoto's thyroiditis, but also being highly frequent in Graves' disease and postpartum thyroiditis (Prummel and Wiersinga, 2005). however, the existence of anti-TPO Abs is not uncommon in normal thyroid subjects. For example, in the NHANES III study, $8.0 \%$ and $14.6 \%$ of euthyroid men and women had such antibodies (Hollowell et al., 2002).

The results of the present study were consistent with these of other authors when they demonstrated that anti-TPO antibodies are most likely detected in subjects with deranged TSH in comparison to those with the usual TSH ( $p$ value 0.001) (Tipu et al., 2018). Similarly, Al Rabia, (2017) has obtained similar results indicating TSH is more often deranged if anti-TPO or anti-TG antibodies are positive. Moreover, it has been found that anti-TPO positivity is associated with $60 \%$ increase in TSH (Brown et al., 2016). In Iran, consistent findings have been observed by Ghoraishian et al., (2006), they studied relationship of anti-TPO with T3, T4, and TSH in nearly two thousand five hundred individuals and found these to be significantly altered in antibody positive group.

IL-22, mainly synthesized by Th17 and Th22 cells, has an important role in the pathogenesis of several inflammatory and autoimmune conditions (Figueroa-Vega et al.,2010; Pan et al., 2009; Pan et al., 2013)

The outcomes of the current investigation were different from others who measured the serum concentration of IL-22 in a large series of recently diagnosed, euthyroid HT patients and compared these findings with those estimated in euthyroid nonHT subjects with nodular goiter and in healthy individuals without thyroid disorders. All HT patients revealed serum IL22 levels significantly higher than those of non-HT patients with nodular goiter or healthy controls, but no differences emerged between goitrous patients and healthy controls. These data indicated that IL-22, whether it is produced by TH17 or Th22 or both, plays special role in the initiation of HT. This is an interesting finding because HT is commonly considered to be a Th1-mediated disease (Ruggeri et al., 2014).

\section{CONCLUSION}

It has been concluded that autoimmune thyroid diseases affected a considerable number of participants with hypothyroidism being the more prevalent over hyperthyroidism and that IL-22 had no evident role in the development or progression of the disease process.

\section{ACKNOWLEDGEMENT}

The authors would like to thanks all participants in this study, thanks is also in order for Duhok central laboratory staff for their help during the course of the work.

\section{REFERENCES}

Al-Rabi, M. W. (2017). Correlation of thyroid antibodies with TSH, T3 and T4 hormones in patients diagnosed with autoimmune thyroid disorders. Pakistan Journal of Pharmaceutical Sciences, volume; 30 (2): 607-612.

Bossowski, A.; Moniuszko, M.; Dabrowska, M.; Rusak, M.; Jeznach, M.; Bodzenta-Łukaszyk, A.; et al., (2013). Role of Th17 cells and IL-17, IL-23 cytokines in pathogenesis of autoimmune thyroid disease in children. Thyroid Researc; 6(Suppl 2): A8.

Brown, C. J. (1999). Skewed X-chromosome inactivation: cause or consequence? J Natl Cancer Inst.; 91: 304-305.

Brown, S. J.; Bremner, A. P.; Hadlow, N. C.; Feddema, P.; Leedman, P. J.; O'Leary, P.C.; et al., (2016). The log TSH-free T4 relationship in a community-based cohort is nonlinear and is influenced by age, smoking and thyroid peroxidase antibody status. Clinical Endocrinology; vol. 85(5): 789796.

Canaris, G. J.; Manowitz, N. R.; Mayor, G.; and Ridgway, E. C.(2000). The Colorado thyroid disease prevalence study. Arch Intern Med, 160:526-34

Carmona, C. A. C.; Bedoya, P. A.; Acevedo, J. B.; and Arias, J.A. C. (2018). Prevalence of Thyroid Disorders in an Institution Providing Health Services in Medellin-Colombia. Translational Biomedicine; 9(2): 149.

Cutolo, M.; Capellino, S.; Sulli, A.; Serioli, B.; Secchi, M. E.; Villaggio, B.; et al. (2006). Estrogens and autoimmune diseases. Ann N Y Acad Sci.; 1089: 538-547.

Fardella, C.; Poggi, H.; Gloger, S.; Rojas, A.; Velasquez, C. G.; Barroileth, S.; et al. (2001) Alta prevalencia de enfermedad tiroidea subclínica en sujetos que concurren a control de salud. Rev Med Chil,; 129: 155-160.

Figueroa-Vega, N.; Alfonso-Pérez, M.; Benedicto, I.; Sánchez-Madrid, F.; González-Amaro, R.; Marazuela, M.; et al., (2010). Increased circulating pro-inflammatory cytokines and Th17 lymphocytes in Hashimoto's thyroiditis. J Clin Endocrinol Metab., 95: 953-962.

Flynn, R. V.; MacDonald, T. M.; Morris, A. D.; Jung, R. T.; and Leese, G.P. (2004). The thyroid epidemiology, audit and research study; thyroid dysfunction in the general population. J Clin Endocrinol Metab.; 89:3879-84.

Ghoraishian, S. M.; Hekmati, M. S. H.; and Afkhami-Ardekani, M. (2006). Relationship between anti-thyroid peroxidase antibody and thyroid function test. Iranian Journal of Immunology, vol.; 3(13): 146-149.

Guo, Y.; Zynat, J.; Xing, S.; Xin, L.; Li, S.; Mammat, N.; et al.,(2018) Immunological changes of $\mathrm{T}$ helper cells in flow cytometer-sorted CD4+ $\mathrm{T}$ cells from patients with Hashimoto's thyroiditis. EXPERIMENTAL AND THERAPEUTIC MEDICINE; 15: 3596-3602,

Gussekloo, J.; van Exel, E.; de Craen, A. J. M.; Meinders, A. E.; Frölich, M.; and Westendorp, R. G. (2004). Thyroid status, disability and cognitive function, and survival in old age. JAMA; 292: 2591-99. 
Hollowell, J. G.; Staehling, N. W.; Flanders, W. D.; Hannon, W. H.; Gunter, E. W.; Spencer, C. A.; et al., (2002) Serum TSH, T4, and thyroid antibodies in the United States population (1988 to 1994): National Health and Nutrition Examination Survey (NHANES III). J Clin Endocrinol Metab.; 87:489-499.

Jonklaas, J.; Bianco, A. C.; Bauer, A. J.; Burman, K. D.; Cappola, A. R.; Celi, F. S.; et al.; (2014). Guidelines for the Treatment of Hypothyroidism: Prepared by the American Thyroid Association Task Force on Thyroid Hormone Replacement. Thyroid; 24(12): 1670-1751.

Leese, G. P.; Flynn, R. V.; Jung, R. T.; Macdonald, T. M,.; Murphy, M. J.; and Morris, A. D. (2008). Increasing prevalence and incidence of thyroid disease in Tayside, Scotland: The Thyroid Epidemiology, Audit and Research Study (TEARS). Clin Endocrinol (Oxf); 68: 311-316.

Moudgil, K. D. and Choubey, D. (2011). Cytokines in Autoimmunity: Role in Induction, Regulation, and Treatment. Journal of Interferon \& Cytokine Research; 31(10): 695-703.

Okosieme, O.; Gilbert, J.; Abraham, P.; Boelaert, K.; Dayan, C.; Gurnell, M.; et al., (2016). "Management of primary hypothyroidism: statement by the British thyroid association executive committee," Clinical Endocrinology; volume 84(6): 799-808.

Oliver, J. E.; and Silman, A. J. (2009). Why are women predisposed to autoimmune rheumatic diseases? Arthritis Res Ther.; 11: 252

Pan, H. F.; Li, X. P.; Zheng, S. G.; and Ye, D. Q. (2013). Emerging role of interleukin-22 in autoimmune diseases. Cytokine Growth Factor Rev.; 24: 51-57.

Pan, H. F.; Zhao, X. F.; Yuan, H.; Zhang, W. H.; Li, X. P.; Wang, G. H.; et al., (2009). Decreased serum IL-22 levels in patients with systemic lupus erythematosus. Clinica Chimica Acta.; 401: 179-180.

Peng, D.; Xu, B.; Wang, Y.; Guo, H. and Jiang, Y.( 2013). A high frequency of circulating Th22 and Th17 cells in patients with new onset Graves' disease. Plos One; 8(7): 1-8

Prummel, M. F.; and Wiersinga, W. M. (2005). Thyroid peroxidase autoantibodies in euthyroid subjects. Best Pract Res Clin Endocrinol Metab.; 19:1-15.
Przybylik-Mazurek, E.; Hubalewska-Dydejczyk, A.; and Huszno, B. (2007) Hypothyroidism on an autoimmune background. Alergol Immunol; 4: 64-69.

Razvi, S.; Bhana, S.; and Mrabeti, S. (2019). Challenges in Interpreting Thyroid Stimulating Hormone Results in the Diagnosis of Thyroid Dysfunction. Review Article. Journal of Thyroid Research: $1-8$

Rubtsov, A. V.; Rubtsova, K.; Kappler, J. W.; and Marrack, P. (2010). Genetic and hormonal factors in female-biased autoimmunity. Autoimmun Rev.; 9: 494-498.

Ruggeri, R. M.; Minciullo, P.; Saitta, S.; Giovinazzo, S.; Certo, R. Campennì, A.; et al., (2014). Serum interleukin-22 (IL-22) is increased in the early stage of Hashimoto's thyroiditis compared to non-autoimmune thyroid disease and healthy controls. HORMONES; 13(3): 338-344

Rydzewska, M.; Jaromin, M.; Pasierowska,I. E.; Stożek, K.; and Artur Bossowski, A. (2018). Role of the T and B lymphocytes in pathogenesis of autoimmune thyroid diseases. Thyroid Research; 11:2.

Shevach, E. M. (2009) Mechanisms of foxp3+ T regulatory cell mediated suppression. Immunity; 30: 636-645.

Sridevi, A.; Rakesh, B.; Amit, G.; Aiswarya, Y.; Anupam, B.; and Channabasappa, S. (2018). Prevalence of Elevated AntiThyroid Peroxidase Antibodies in Subclinical Hypothyroidism. International Journal of Contemporary Medical Research; Volume 5 (3): 2454-7379

Szczeblowska, D.; Hebzda, A.; and Wojtuń, S. (2011) Autoimmune diseases in medical practice. Pediatr Med.; 7: 218-222.

Tipu, H. N.; Ahmed, D.; Bashir, M. M.; and Asif, N. (2018). Significance of Testing Anti-Thyroid Autoantibodies in Patients with Deranged Thyroid Profile. Journal of Thyroid Research: $1-5$.

Vanderpump, M. (2005) The epidemiology of thyroid diseases $\left(9^{\text {th }}\right.$ edition) Philadelphia.

Viswanath, D. (2013). Understanding Autoimmune Diseases-A Review. IOSR Journal of Dental and Medical Science; Volume. 6(6): 08-15. 